10 The Complete Letters of Oscar Wilde, ed. Merlin Holland and Rupert Hart-Davis (New York: Henry Holt, 2000), 713.

11 Oscar Wilde, “The Gospel According to Walt Whitman," Pall Mall Gazette (January 25,1889$), 3$.

12 Lady Jane Francesca Wilde (1826-1895), aka "Speranza," was a prominent Irish nationalist poet.

13 With Walt Whitman in Camden, ed. Gertrude Traubel (Carbondale: Southern I1linois University Press, 1964), 5:284.

\title{
AN UNPUBLISHED WHITMAN MANUSCRIPT ON EMERSON
}

Kendall Reed has recently added an unpublished Whitman manuscript to his collection of Whitman materials. It is a short note about the poet's reading of Emerson's later work. Here is a transcription of the manuscript, which is reprinted on the back cover of this issue of $W W Q R$ : "It is very plain ^after ${ }^{\wedge}$ reading Emerson's early forenoon essays, and then those of his elder age that the latter are not the ${ }^{\wedge}$ consecutive ${ }^{\wedge}$ fruits or crowning results of the former".

The manuscript is undated and is mounted in a frame with a copy of an 1871 photo of the poet taken by Gurney and Son, along with a note in an unknown hand that reads: "A bit of Walt Whitman MS. / From / J. H. Johnston New York / To His Grace, the Archbishop / of Canterbury / 1904." Johnston (1837-1919) was a New York jeweler and a loyal friend and supporter of the poet; Whitman visited Johnston's home frequently in the 1870s and 1880s. The Archbishop of Canterbury in 1904 was Randall Thomas Davidson, $1^{\text {st }}$ Baron Davidson of Lambeth (1848-1930); he served as archbishop from 1903 to 1928. Johnston's relationship to the archbishop is unknown, but the archbishop did visit the United States in 1904 to celebrate the one-hundredth anniversary of the Episcopal cathedral in Quebec and to attend the triennial general convention of the Protestant Episcopal Church, held in Boston that October. He arrived in New York in late August, where he was met by a distinguished group of New Yorkers and taken by train, in J. Pierpont Morgan's private car, to Quebec. While in North America, the archbishop toured Canada and the United States, visiting Montreal, Toronto, Niagara Falls, Albany, and Washington, D.C., where he met with President Theodore Roosevelt. During his stay, the archbishop came to New York and attended several banquets with prominent churchgoers, receiving many gifts. It is likely that this Whitman memento from Johnston was one of them.

The manuscript is illuminating because it is one of a number of prose fragments in which Whitman expresses some deep reservations about Emerson. One of those manuscripts was printed in WWQR in the Summer/Fall 2000 issue; in that fragment, Whitman questions Emerson's "sense of Deity" and 
complains that Emerson substitutes "intellect" for the "Deific figure," gaining "polish" at the expense of "heat": "He is too cautious," Whitman writes in the margin of that manuscript. The newly discovered fragment builds on this analysis, as Whitman registers his sense of a decline in Emerson's powers as he ages, perhaps detecting in Emerson a hint of what was happening to his own fading poetic powers in the 1870 s and 1880 s.

All of these notes seem to be jottings that would eventually coalesce into Whitman's essay, "Emerson's Books, (The Shadows of Them)," which appeared in 1880 in the Boston Literary World. There Whitman lays out his deepest concerns about Emerson's work and focuses on "the bare spots and darknesses" in his work, noting that as a young man he himself had "Emerson-on-the-brain" and "address'd him in print as 'Master,' and for a month or so thought of him as such," but, like "most young people of eager minds," he "pass[ed] through this stage of existence." This new manuscript lets us know that Whitman, despite his disappointment over what became of Emerson in his old age, still found some excitement in returning to the Concord sage's "forenoon essays." 